\title{
BOTULINUM TOXIN A TREATMENT OF DELAYED FACIAL PALSY IN A RANDOMIZED TRIAL
}

Mikhail A. Akulov ${ }^{1}$, Sergey V. Tanyashin ${ }^{1}$, Dmitriy Y. Usachev ${ }^{1}$, Vadim N. Shimanskiy ${ }^{1}$, Olga R. Orlova ${ }^{2}$, Vladimir O. Zakharov ${ }^{1}$, Vasiliy V. Karnaukhov ${ }^{1}$, Mariya V. Kolycheva ${ }^{1}$, Svetlana E. Khatkova ${ }^{3}$, Sergej B. Bolevich ${ }^{4}$ and Aleksandra S. Orlova ${ }^{4}$

${ }^{I}$ N.N. Burdenko Research Institute of Neurosurgery, Russian Academy of Sciences, Moscow, Russia

${ }^{2}$ I.M. Sechenov First Moscow State Medical University, Department of Neurology, Moscow, Russia ${ }^{3}$ Federal State Automatic Institution Medical Rehabilitation Center, Moscow, Russia

${ }^{4}$ I.M. Sechenov First Moscow State Medical University, Department of Human Pathology, Moscow, Russia

\author{
TRETMAN ODLOŽENE PARALIZE FACIJALISA BOTULINOM \\ TOKSINOM A-RANDOMIZIRANA STUDIJA \\ Mihail A. Akulov ${ }^{1}$, Sergej V. Tanjašin1, Dmitrij I. Usačeva, Vadim N. Šimanskij ${ }^{1}$, Olga R. Orlova ${ }^{2}$, Vladimir O. Zaharov ${ }^{1}$, \\ Vasilij V. Karnauhov1, Marija V. Količeva ${ }^{1}$, Svetlana E. Hatkova ${ }^{3}$, Sergej B. Bolevich ${ }^{4}$ i Aleksandra S. Orlova ${ }^{4}$ \\ ${ }^{I}$ N.N. Istraživački institut za neurohirurgiju Burdenko, Ruska akademija nauka, Moskva, Rusija \\ ${ }^{2}$ I. M. Sechenov Prvi Moskovski državni medicinski univerzitet, Odeljenje za neurologiju, Moskva, Rusija \\ ${ }^{3}$ Savezni državni centar za medicinsku rehabilitaciju, Moskva, Rusija \\ ${ }^{4}$ I. M. Sečenov Prvi Moskovski državni medicinski univerzitet, Odeljenje za ljudsku patologiju, Moskva, Rusija
}

\begin{abstract}
Introduction: Delayed facial palsy (DFP) is a common complication appearing $\geq 3$ days after neurosurgery. In cases where glucocorticoids are contraindicated, other treatments are needed. Methods: The efficacy of BoNT-A injections was evaluated in patients with DFP after vestibular schwannoma resection. Patients received: Group I, BoNT-A (40-50 IU); Group II, prednisolone (1 mg/kg per day, 5-7 days); Group III, glucocorticoids with BoNT-A; Group IV, refused treatment. Functional efficacy was assessed. Results: Among 75 patients, pretreatment facial nerve dysfunction was mild, moderate, and moderate-to-severe in $48.0 \%, 33.3 \%$, and $18.7 \%$, respectively. One month post-treatment initiation, Group III had a significantly higher rate of facial symmetry normalization versus Groups II and IV $(P<0.05)$. After 3 months, complete recovery of facial nerve function was significantly higher in Groups I-III versus Group IV $(P<0.05)$. Conclusion: BoNT-A injections may be recommended for DFP treatment to attenuate facial asymmetry and improve functional recovery.
\end{abstract}

Keywords: delayed facial palsy, botulinum toxin type $A$, house-brackmann scale, rehabilitation.

\section{SAŽETAK}

Uvod: Odložena paraliza facijalnog nerva (OPF) je česta komplikacija koja se javlja $\geq 3$ dana nakon neurohirurške intervencije. $U$ slučajevima kada su glukokortikoidi kontraindikovani, potrebni su drugi tretmani. Metode: Efikasnost injekcija BOTX-A procenjena je kod pacijenata sa DFP nakon resekcije vestibularnog švanoma. Pacijenti su bili podeljeni na: I grupu, BOTX-A (40-50 IU); II grupa, prednizolon (1 mg/kg dnevno, 5-7 dana); III grupa, kombinovana primena glukokortikoida sa BOTX-A; IV grupa, odbila je lečenje. Procenjena je funkcionalna efikasnost svakog tretmana. Rezultati: Među 75 pacijenata, disfunkcija facijalnog nerva pre tretmana bila je blaga, umerena i umerena do teška kod 48,0\%, 33,3\% i 18,7\%. Jednomesečno nakon započinjanja tretmana, III grupa je imala značajno veću stopu normalizacije simetrije lica $u$ odnosu na II i IV grupu $(P<0,05)$. Posle 3 meseca, potpuni oporavak funkcije facijalnog nerva bio je značajno veći u I, II i III grupi u odnosu na IV $(P<0,05)$. Zaključak: Injekcije BOTX-A mogu se preporučiti za lečenje OPF-om radi ublažavanja asimetrije lica i poboljšanja funkcionalnog oporavka.

Ključne reči: odložena paraliza lica, botulinum toksin tip A, house-brackamannova skala, rehabilitacija.

\section{ABBREVIATIONS \\ BoNT A - botulinum toxin type \\ ACGI - Clinical Global Impression \\ DFP - delayed facial palsy \\ FDI - Facial Disability Index \\ GC - glucocorticoid \\ HB - House-Brackmann [scale]}

PF - Physical Function [subscale of the Facial Disability Scale]

SD - standard deviation

SWBF - Social/Well-Being Function [subscale of the Facial Disability Scale]

VSR - vestibular schwannoma resection

\section{sciendo}

UDK: 616.833.17-009.11

Ser J Exp Clin Res 2021; 22 (2): 137-144

DOI: $10.2478 /$ sjecr-2020-0063
Corresponding author:

Mikhail A. Akulov, N.N
Burdenko Research Institute of Neurosurgery, Russian Academy of Sciences, 125047, Moscow, Russia. 


\section{INTRODUCTION}

Facial nerve injury after cerebellopontine angle surgery, especially after vestibular schwannoma resection, remains a challenging problem that significantly decreases the quality of life of patients in the postoperative period (1).

Depending on the time of deterioration of facial nerve function, one can identify facial nerve palsy with early (immediately after the surgery) and late (delayed) onset (2-4). Delayed facial palsy (DFP) is less widely studied in scientific literature compared to acute facial nerve palsy. DFP is characterized by spontaneous palsy of mimic muscles in patients with intact facial nerve function during the early postoperative period [4].

According to current research data, the prevalence of DFP after vestibular schwannoma resection is $4.8-41 \%(3,4)$, with a mean prevalence of $19 \%$ (2). There is significant variability in the definition of 'delayed facial neuropathy', making it difficult to compare published research data. Some authors diagnose DFP in all patients with any degree of facial nerve function deterioration emerging after the initial postoperative assessment (5), or between the initial postoperative assessment and follow-up assessment 3-5 days later (6). Others only consider patients with facial nerve function deterioration emerging several days after surgery $(2,4)$.

In contrast to idiopathic facial palsy (Bell's palsy), which is primarily associated with infection and inflammation, ischemia, or compression [7, 8], DFP pathophysiology in the postoperative period remains unclear. Deterioration of facial nerve function may be a result of several factors including perineural edema, vascular spasm, and reactivation of viral infection [6,9-11]. The most probable causes are vascular spasm and local perineural edema (which are more pronounced compared to idiopathic neuropathy because of the close anatomic relationship between the acoustic-facial group of nerves and tumor, resulting in surgical injury during tumor resection), developing during the first few days after the intervention and described as postoperative $(12,13)$.

The etiology of DFP is largely unknown, but there is evidence to suggest that it may be related to viral reactivation or the surgical approach. The research literature indicates an elevation of antibody titer in patients who develop DFP after surgery to herpes simplex virus types 1 and 2 and also to the varicella-zoster virus $(9,11)$. Nevertheless, current preoperative algorithms (14) do not support routine prevention of viral infection reactivation. Current research focusing on the association of the surgical approach to the resection of vestibular schwannomas and the development of DFP has provided inconclusive results. Several small studies have failed to demonstrate a correlation between different surgical approaches and the development of $\operatorname{DFP}(3,5)$. At the same time, some studies have shown a 2- to 3 -fold increase of risk of deterioration of facial nerve function in the case of the retrosigmoid approach to vestibular schwannoma $(2,15)$. Some authors suggest that bone dust dispersion, resulting from insufficient irrigation in the posterior cranial fossa during grinding of the petrous pyramid and internal auditory canal during the translabyrinthine and retrosigmoid approaches, may lead to increased local inflammatory reaction and development of DFP (2). It is assumed that prolonged decompression of facial nerves in the translabyrinthine approach decreases the risk of postoperative neural edema (2). However, the choice of a surgical approach is rarely based on current research results, presuming that DFP treatment in $>85 \%$ of cases results in restoration of facial nerve function to grade I-II on the House-Brackmann (HB) facial paralysis scale (2, 16).

Large tumor size (Koos stage III-IV), tumor structure, and the relationship of the nerve with the tumor have been assessed as risk factors for DFP $(2,6)$. A large volume of resection is likely to be associated with more pronounced edema of surrounding tissues, and viral infection reactivation may also occur in the postoperative period (6).

At present, a standard of care for DFP is lacking, because the etiology of the condition is not fully understood. Many researchers have tried glucocorticoid (GC) therapy (17). However, the broad spectrum of adverse effects associated with GC treatment limits its use and has necessitated the search for additional highly effective and safe treatment strategies (18). Botulinum toxin type A (BoNT-A) has demonstrated efficacy in the treatment of acute facial nerve injury after neurosurgical interventions, which allows it to be considered as a therapeutic option for DFP (19).

This study was performed to evaluate the efficacy and safety of BoNT-A therapy in patients with DFP after vestibular schwannoma resection, including patients with medical contraindications for GC therapy.

\section{METHODS}

\subsection{Study design}

This single-center, open-label, rater-blinded, randomized study recruited patients with DFP developing $\geq 3$ days after vestibular schwannoma resection in the Burdenko National Scientific and Practical Center for Neurosurgery (Moscow, Russia) from 2012 to 2017 . The study period was 3 months.

Primary exclusion criteria included facial nerve paresis of nonsurgical etiology and complete rupture of the facial nerve during surgical resection of the tumor and noncompliance with the treatment regimen (including control visits).

The study protocol was approved by the local Ethical Committee of the N.N. Burdenko Research Institute of Neurosurgery, Moscow, Russia. All procedures complied with the standards established by the Declaration of Helsinki and written, informed consent was gathered from all patients.

Patients were assigned to 4 treatment groups as described below; those assigned to Groups II or III were randomized in a 1:1 ratio. Group I included patients who did not receive GC 
therapy because of contraindications to GC treatment, and thus received injections of incobotulinumtoxinA (Xeomin ${ }^{\circledR}$, Merz Pharmaceuticals GmbH, Frankfurt am Main, Germany) into mimic muscles on the intact side to decrease elevated muscle tone (which determines the level of traction of mimic muscles towards the intact side) and provide relative facial symmetry. Patients in this group received a single cycle of consecutive injections into mimic muscles on the intact side: $\mathrm{m}$. frontalis ( $3 \mathrm{U}$ per 2 injection points), $\mathrm{m}$. corrugator supercilii (2-4 U per 2 injection points), $\mathrm{m}$. levator labii superioris alaeque nasi $(2 \mathrm{U}), \mathrm{m}$. zygomaticus minor and major $(2 \mathrm{U})$, $\mathrm{m}$. levator labii superioris $(2 \mathrm{U}), \mathrm{m}$. levator anguli oris $(2 \mathrm{U})$, $\mathrm{m}$. orbicularis oris (1 injection point above the upper lip-1 $\mathrm{U}), \mathrm{m}$. depressor labii inferioris (1-2 U), m. mentalis (2 U) and $\mathrm{m}$. platysma (4-5 U per 2-4 injection points). The total dose of incobotulinumtoxinA was $40-50 \mathrm{U}$ per patient and the total number of injection points varied between 10 and 15 .

Patients in Group II received oral prednisolone tablets soon after the development of facial palsy, $1 \mathrm{mg} / \mathrm{kg} /$ day, once daily for 5-7 days with a subsequent gradual tapering off and discontinuation over 3-4 days. Patients in Group III received GC treatment (as per Group II) combined with BoNT-A injections similar to Group I. Patients in Group IV refused any treatment and only visited the clinic for dynamic evaluation.

Koos classification was used for grading tumor size: (i) Koos Grade I: tumor involves only the internal auditory canal; extracranial diameter $1-10 \mathrm{~mm}$; purely intracanalicular tumor limited to the internal auditory canal only; (ii) Koos Grade II: tumor causes widening of the internal auditory canal and extends into the cerebellopontine angle; diameter reaches $11-20 \mathrm{~mm} ;<2 \mathrm{~cm}$ extracanalicular/cerebellopontine angle extension without brainstem compression; (iii) Koos Grade III: tumor reaches brainstem, but does not cause compression; diameter reaches $21-30 \mathrm{~mm}$; extracanalicular/cerebellopontine angle extension $>2 \mathrm{~cm}$, with no brainstem compression; (iv) Koos Grade IV: tumor causes brainstem compression; diameter reaches $>30 \mathrm{~mm}$; extracanalicular/cerebellopontine angle extension with any degree of brainstem compression.

\subsection{Efficacy assessments}

Treatment efficacy was assessed clinically. HB scale assessments were performed by an independent researcher who was blinded to the treatment administered to each patient. The severity of facial palsy was assessed using the HB scale at baseline, 1 month, and 3 months after treatment initiation (Grade 1: normal facial function; Grade 2: mild dysfunction; Grade 3: moderate weakness; Grade 4: moderate-to-severe weakness; Grade 5: severe weakness). At the end of the study, patients completed a Clinical Global Impression (CGI) scale. At baseline, 1 month and 3 months after treatment initiation, patients also completed the Facial Disability Index (FDI) self-assessment scale, which assesses physical function and social wellbeing on a combined scale from 0 (worst) to 200 (best).

\subsection{Statistical analysis}

Changes in mean HB scale scores were analyzed using 1sample t-tests with no replacement of missing data. Comparison between groups for functional improvement was performed by student's t-test. A P-value of $<0.05$ was considered significant. All statistical analyses were performed using SAS version 8.2 or later (SAS Institute, Cary, NC, USA).

\subsection{Safety assessments}

Safety assessments included the monitoring of adverse events based on patient-reported events at follow-up visits.

\section{RESULTS}

\subsection{Patient baseline characteristics}

Seventy-five patients, 31-64 years of age (mean age $48.47 \pm 7.15$ years), were recruited and assigned to treatment groups as follows: (i) Group I: 20 patients: 11 men (55.0\%) and 9 women $(45.0 \%)$, including patients who did not receive GC therapy because of the presence of gastric or duodenal ulcer $(\mathrm{n}=5 ; 25.0 \%)$, severe chronic heart failure $(\mathrm{n}=5$; $25.0 \%)$, type 2 diabetes mellitus $(\mathrm{n}=4 ; 20.0 \%)$ and stage III hypertension ( $\mathrm{n}=8 ; 40.0 \%$ ); (ii) Group II: 16 patients: 7 men (43.8\%) and 9 women (56.2\%); (iii) Group III: 18 patients: 10 men (55.6\%) and 8 women (44.4\%); (iv) Group IV: 21 patients: 9 men $(42.9 \%)$ and 12 women $(57.1 \%)$.

During the study, an analysis was performed on the topographic or anatomic aspects of the facial nerve and tumor size in patients with DFP. In 43 patients $(57.3 \%)$, tumor size was 21-30 $\mathrm{mm}$; tumor sizes $<20 \mathrm{~mm}$ and $>30 \mathrm{~mm}$ were identified in 29 patients $(38.7 \%)$ and 3 patients $(4.0 \%)$, respectively. In 61 patients $(81.3 \%)$, the facial nerve was situated along the anterior-inferior surface of the tumor and, in 54 patients $(72.0 \%)$, it was difficult to separate the facial nerve from the surface of the tumor due to arachnoid commissures; in 32 patients $(42.7 \%)$, the nerve could not be visualized as a result of significant thinning or stretching. In 48 patients $(64.0 \%)$, oral tumor expansion was observed predominantly and, in most cases (54 patients, 72.0\%), the tumor had an unclear border and a soft membrane. In 40 patients $(53.3 \%)$, radical tumor resection was performed, which was accompanied by more active surgical manipulations near facial nerve structures and a higher degree of traumatization (Table 1).

DFP developed typically after $\geq 11$ days (up to 23 days) after surgery $(\mathrm{n}=40 ; 53.3 \%)$ and less often on Days $6-10$ $(\mathrm{n}=24 ; 32.0 \%)$ or Days $3-5$ post-operation $(\mathrm{n}=13 ; 17.3 \%)$ (Table 1). No differences between the studied groups in topographic or anatomic aspects of the facial nerve, tumor size, or time to postoperative development of mimic muscle palsy were observed. 
Table 1. Baseline demographic and clinical characteristics

\begin{tabular}{|c|c|c|c|c|}
\hline & $\begin{array}{l}\text { Group I } \\
(\mathrm{n}=20)\end{array}$ & $\begin{array}{l}\text { Group II } \\
(\mathrm{n}=16)\end{array}$ & $\begin{array}{l}\text { Group III } \\
(\mathrm{n}=18)\end{array}$ & $\begin{array}{c}\text { Group IV } \\
(\mathrm{n}=21)\end{array}$ \\
\hline Mean \pm SD age, years & $50.3 \pm 8.3$ & $49.6 \pm 7.5$ & $52.3 \pm 7.9$ & $45.0 \pm 7.3$ \\
\hline Female, n (\%) & $9(45.0)$ & $9(56.2)$ & $8(44.4)$ & $12(57.1)$ \\
\hline Male, n (\%) & $11(55.0)$ & $7(43.8)$ & $10(55.6)$ & $9(42.9)$ \\
\hline \multicolumn{5}{|c|}{ Topographic and anatomic aspects of the facial nerve, $\mathrm{n}(\%)$} \\
\hline $\begin{array}{l}\text { Facial nerve location on anterior-inferior surface } \\
\text { of tumor }\end{array}$ & $15(75.0)$ & $15(93.8)$ & $14(77.8)$ & $17(81.0)$ \\
\hline $\begin{array}{l}\text { Visual control of facial nerve location is } \\
\text { impossible }\end{array}$ & $9(45.0)$ & $7(43.8)$ & $8(44.4)$ & $8(38.1)$ \\
\hline $\begin{array}{l}\text { Arachnoid commissures of the tumor with facial } \\
\text { nerve }\end{array}$ & $14(70.0)$ & $11(68.8)$ & $14(77.8)$ & $15(71.4)$ \\
\hline $\begin{array}{l}\text { Oral direction of tumor growth relative to a } \\
\text { normal axis of facial nerve }\end{array}$ & $12(60.0)$ & $10(62.5)$ & $12(66.7)$ & $14(66.7)$ \\
\hline $\begin{array}{l}\text { Surface of arachnoid dissection is unclear or } \\
\text { absent }\end{array}$ & $14(70.0)$ & $11(68.8)$ & $13(72.2)$ & $16(76.2)$ \\
\hline Radical tumor resection & $10(50.0)$ & $9(56.3)$ & $10(55.6)$ & $11(52.4)$ \\
\hline \multicolumn{5}{|l|}{ Tumor size, $\mathrm{n}(\%)$} \\
\hline 11-20 mm (Koos Grade II) & $7(35.0)$ & $7(43.8)$ & $7(38.9)$ & $8(38.1)$ \\
\hline 21-30 mm (Koos Grade III) & $12(60.0)$ & $9(56.3)$ & $10(55.6)$ & $12(57.1)$ \\
\hline$>30 \mathrm{~mm}$ (Koos Grade IV) & $1(5.0)$ & - & $1(5.6)$ & $1(4.8)$ \\
\hline \multicolumn{5}{|c|}{ Time to development of mimic muscle palsy after surgical treatment, $\mathrm{n}(\%)$} \\
\hline $3-5$ days & $4(20.0)$ & $3(18.8)$ & $2(11.1)$ & $4(19.0)$ \\
\hline 6-10 days & $6(30.0)$ & $5(31.3)$ & $6(33.3)$ & $7(33.3)$ \\
\hline$>11$ days & $10(50.0)$ & $8(50.0)$ & $10(55.6)$ & $10(47.6)$ \\
\hline
\end{tabular}

BoNT A - botulinum toxin type A,

GC - glucocorticoid,

SD - standard deviation,

Group I $(n=20)$ received BoNT-A injections,

Group II $(\mathrm{n}=16)$ received oral prednisolone tablets,

Group III $(\mathrm{n}=18)$ received combined GC and BoNT-A injections,

Group IV $(\mathrm{n}=21)$ did not receive any treatment.

\subsection{Efficacy after treatment}

Before the start of treatment, facial nerve function $\mathrm{HB}$ scale score was 2 points in 36 patients $(48.0 \%), 3$ points in 25 patients $(33.3 \%)$, and 4 points in 14 patients $(18.7 \%)$. There was an improvement in facial nerve function in all groups 1 month after the start of treatment; however, a significantly higher rate of facial symmetry normalization was observed in patients receiving GC therapy combined with BoNT-A injections (Group III) compared to Groups II and IV $(\mathrm{P}<0.05)$. Low-grade facial nerve dysfunction in Group III was observed in a significantly lower percentage of patients, compared to other groups $(\mathrm{P}<0.05)$.
After 3 months of treatment, a significantly higher rate of complete recovery of facial symmetry on the HB scale score was observed in all groups on active treatment (Groups IIII), compared to Group IV $(\mathrm{P}<0.05)$. A trend toward complete facial symmetry restoration was observed in patients receiving GC therapy combined with BoNT-A injections compared with BoNT-A alone or prednisolone, although the difference did not reach statistical significance (Table 2). 
Table 2. Changes in facial asymmetry HB scale score

\begin{tabular}{|c|c|c|c|c|c|c|}
\hline \multirow[b]{2}{*}{ Group } & \multirow{2}{*}{$\begin{array}{l}\text { Follow-up } \\
\text { period }\end{array}$} & \multicolumn{5}{|c|}{ HB scale score } \\
\hline & & $\begin{array}{c}\text { Grade } 1 \\
\mathrm{n}(\%)\end{array}$ & $\begin{array}{c}\text { Grade } 2 \\
\mathrm{n}(\%)\end{array}$ & $\begin{array}{c}\text { Grade } 3 \\
\mathrm{n}(\%)\end{array}$ & $\begin{array}{c}\text { Grade } 4 \\
\mathrm{n}(\%)\end{array}$ & Mean (SD) \\
\hline \multirow{2}{*}{$\begin{array}{c}\mathrm{I} \\
(\mathrm{n}=20)\end{array}$} & Baseline & - & $9(45.0)$ & $7(35.0)$ & $4(20.0)$ & $2.75(0.79)$ \\
\hline & $\begin{array}{l}1 \text { month } \\
\text { post-treatment }\end{array}$ & $12(60.0)$ & $5(25.0)$ & $3(15.0)$ & - & $1.55(0.76)^{*}$ \\
\hline \multirow{4}{*}{$\begin{array}{c}\text { II } \\
(n=16)\end{array}$} & $\begin{array}{c}3 \text { months } \\
\text { post-treatment }\end{array}$ & $15(75.0)$ & $3(15.0)$ & $2(10.0)$ & - & $1.35(0.67)^{*}$ \\
\hline & Baseline & - & $8(50.0)$ & $5(31.3)$ & 3 (18.7) & $2.69(0.79)$ \\
\hline & $\begin{array}{c}1 \text { month } \\
\text { post-treatment }\end{array}$ & $9(56.2)$ & $5(31.3)$ & $2(12.5)$ & - & $1.56(0.73)^{\dagger}$ \\
\hline & $\begin{array}{c}3 \text { months } \\
\text { post-treatment }\end{array}$ & $14(87.5)$ & $2(12.5)$ & - & - & $1.13(0.34)^{\dagger}$ \\
\hline \multirow{2}{*}{$\begin{array}{c}\text { III } \\
(n=18)\end{array}$} & Baseline & - & $8(44.4)$ & $6(33.3)$ & $4(22.3)$ & $2.78(0.81)$ \\
\hline & $\begin{array}{c}1 \text { month } \\
\text { post-treatment }\end{array}$ & $16(88.9)$ & $2(11.1)$ & - & - & $1.11(0.32)^{*}$ \\
\hline \multirow{4}{*}{$\begin{array}{c}\text { IV } \\
(n=21)\end{array}$} & $\begin{array}{c}3 \text { months } \\
\text { post-treatment }\end{array}$ & $17(94.4)$ & $1(5.6)$ & - & - & $1.01(0.24)^{*}$ \\
\hline & Baseline & - & $11(52.4)$ & $7(33.3)$ & $3(14.3)$ & $2.62(0.74)$ \\
\hline & $\begin{array}{l}1 \text { month } \\
\text { post-treatment }\end{array}$ & $6(28.6)$ & $6(28.6)$ & $6(28.6)$ & $3(14.3)$ & $2.29(1.06)$ \\
\hline & $\begin{array}{l}3 \text { month } \\
\text { post-treatment }\end{array}$ & $8(38.1)$ & $5(23.8)$ & $5(23.8)$ & $3(14.3)$ & $2.14(1.11)$ \\
\hline
\end{tabular}

BoNT A - botulinum toxin type A, GC - glucocorticoid, HB - House-Brackmann

The severity of facial palsy was assessed as follows: Grade 1, normal facial function; Grade 2, mild dysfunction; Grade 3, moderate weakness; Grade 4, moderate-to-severe weakness; Grade 5, severe weakness. Assessments were performed at baseline, 1 month, and 3 months after treatment initiation by an independent assessor who was blinded to the administered treatments.

Group I $(\mathrm{n}=20)$ received BoNT-A injections; Group II $(n=16)$ received oral prednisolone tablets; Group III $(\mathrm{n}=18)$ received combined $\mathrm{GC}$ and BoNT-A injections; Group IV $(n=21)$ did not receive any treatment.
${ }^{*} P<0.05$ for Group I versus Group IV (two-tailed probability).

$\dagger P<0.05$ - statistically significant difference between Groups II and IV.

$\$ P<0.001$ - statistically significant difference between Groups III and IV.

Most patients in Groups I-III were satisfied with the results of treatment and reported notable improvement of mimic muscle function as rated by CGI scale score. Some patients in Group IV reported an improvement, but the substantial improvement rate in that group was significantly lower than in Groups I-III $(P<0.05)$ (Fig. 1).

Figure 1. Improvement in facial symmetry score during treatment

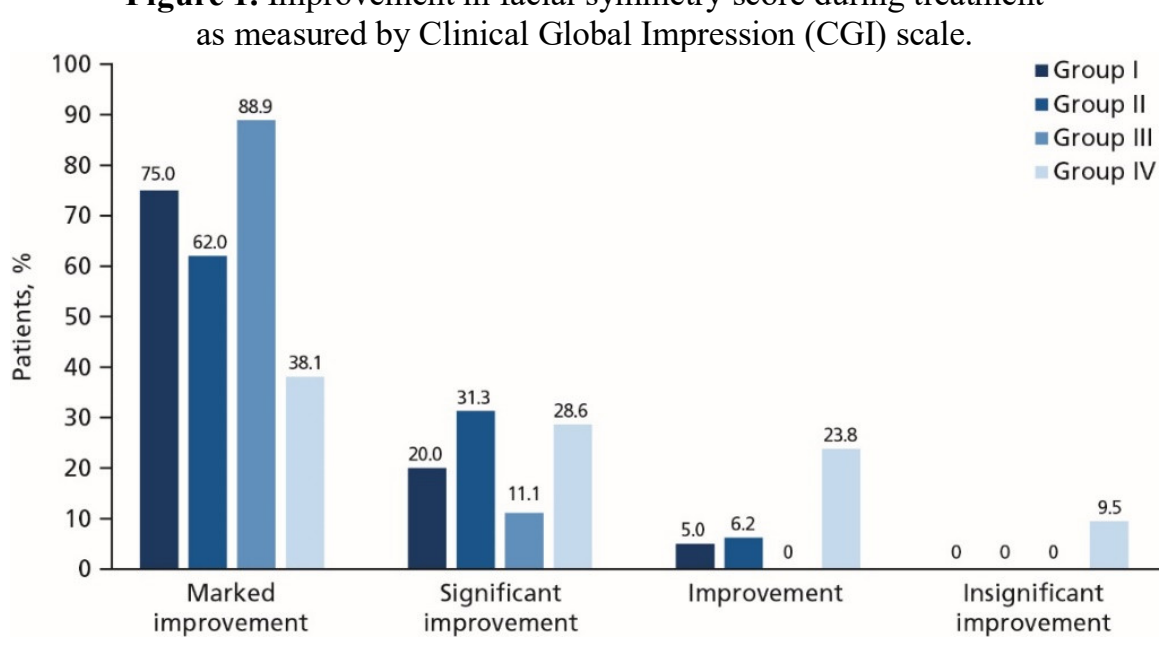


Patients completed the CGI assessment at the end of the study (3 months after treatment initiation). Group I $(\mathrm{n}=20)$ received botulinum toxin type A (BoNT-A) injections; Group II $(n=16)$ received oral prednisolone tablets; Group III $(\mathrm{n}=18)$ received combined glucocorticoid and BoNT-A injections; Group IV $(n=21)$ did not receive any treatment.

One month after the start of treatment, there was a significant improvement in physical and social functioning scores on the FDI scale in all groups; however, the mean (SD) FDI score in the Physical Function (PF) and Social/Well-Being Function (SWBF) subscales in Group III was higher than that in other groups $(P<0.05)$ (Table 3$)$. Three months after the start of treatment, the mean (SD) FDI score in the PF and SWBF subscales in Group IV was lower than in other groups $(P<0.05)$ (Table 3).

Table 3. FDI scale scores.

\begin{tabular}{|c|c|c|c|c|c|}
\hline Follow-up period & $\begin{array}{l}\text { FDI subscale score, } \\
\text { mean (SD) }\end{array}$ & Group I & Group II & Group III & Group IV \\
\hline \multirow{2}{*}{ Baseline } & $\mathrm{PF}$ & $39.0(10.9)$ & $39.3(9.4)$ & 38.1 (11.9) & $34.5(11.4)$ \\
\hline & SWBF & $62.2(9.0)$ & $61.6(6.5)$ & $63.6(7.9)$ & $62.9(5.9)$ \\
\hline \multirow{2}{*}{$\begin{array}{l}1 \text { month } \\
\text { post-treatment }\end{array}$} & $\mathrm{PF}$ & $77.3(8.0)$ & $78.3(6.7)$ & $83.3(5.9)^{*, \dagger}$ & $66.9(12.6)^{\ddagger, s,}$ \\
\hline & SWBF & $83.0(6.1)$ & $86.4(7.2)$ & $92.0(4.9)^{*, \dagger}$ & $79.0(11.3)^{\natural}$ \\
\hline \multirow{2}{*}{$\begin{array}{l}3 \text { months } \\
\text { post-treatment }\end{array}$} & $\mathrm{PF}$ & $91.5(3.3)$ & $89.7(5.8)$ & $91.4(2.3)$ & $75.2(9.4)^{\ddagger, \delta, \|}$ \\
\hline & SWBF & $90.0(5.6)$ & $90.9(6.1)$ & 92.9 (2.6) & $77.9(11.4)^{\sharp, s,}$ \\
\hline
\end{tabular}

BoNT-A - botulinum toxin type A, FDI - Facial Disability Index,

GC - glucocorticoid, PF - Physical Function,

SWBF - Social/Well-Being Function, SD - standard deviation

FDI self-assessment by patients rated PF and SWBF at baseline, 1 month, and 3 months after treatment initiation on a combined scale from 0 (worst) to 200 (best).

Group I $(n=20)$ received BoNT-A injections; Group II $(\mathrm{n}=16)$ received oral prednisolone tablets; Group III $(\mathrm{n}=18)$ received combined GC and BoNT-A injections; Group IV $(n=21)$ did not receive any treatment.

${ }^{*} P<0.05$ for Group I versus Group III.

${ }^{\dagger} P<0.05$ for Group II versus Group III.

${ }^{\sharp} P<0.01$ for Group I versus Group IV.

$\S P<0.05$ for Group II versus Group IV.

' $P<0.05$ for Group III versus Group IV.

All two-tailed probability.

\subsection{Safety}

Adverse events associated with BoNT-A treatment were observed in 2 patients (10.0\%) in Group I, including eyebrow ptosis (1 patient, $5.0 \%$ ) and difficulty speaking as a result of mimic muscle weakness (1 patient, $5.0 \%$ ), which resolved within 1 month. In Group III, 1 patient (5.6\%) reported pain at the injection points. All adverse symptoms resolved without treatment and did not require intervention.

Treatment with GCs resulted in elevated blood pressure $(135 / 90 \mathrm{~mm} \mathrm{Hg})$ in Group II after 2 days of treatment (1 patient, $6.25 \%$ ) and elevated blood glucose on Day 9 of GC treatment during the dose-reduction period (1 patient, $6.25 \%)$. Patients in Group III reported epigastric discomfort (1 patient, 5.6\%) and elevated blood glucose on Day 8 of GC treatment during the dose-reduction period (1 patient, 5.6\%). In Groups II and III, elevated blood glucose resulted in GC treatment discontinuation, while other adverse symptoms resolved without treatment and did not require intervention.

\section{DISCUSSION}

The results reported in this study show that active treatment of DFP can result in significantly improved recovery compared with no treatment. After 1 month, BoNT-A injections combined with GC therapy showed significantly improved facial symmetry (HB scale score) compared with prednisolone, and improved physical and social functioning (FDI scale score) compared with all other groups. After 3 months, all active treatment groups showed improved HB, FDI and CGI scale scores compared with those receiving no treatment.

Large tumor size has been investigated as a potential factor for increased risk of DFP development after vestibular schwannoma resection $[2,6]$. In the study reported here, $61.3 \%$ of patients had tumors of Koos Grade 3-4 and all had tumors of Koos Grade $\geq 2$.

A retrospective cohort study demonstrated that patients who developed DFP were more likely to have undergone total resection compared with those without DFP $(83 \%$ and $71 \%$, respectively; odds ratio $=2.03,95 \%$ confidence interval $=1.00-4.18, P=0.05)$ [2]. In our study, total resection had been performed in $53.3 \%$ of patients with DFP. 
Suitable therapy offers a favorable prognosis for functional recovery of DFP. One month after the development of facial nerve palsy, a complete or almost complete recovery can be generally achieved when timely and adequate treatment is given. Our results agree with published global literature: most patients can achieve full recovery of function [3, $4,16]$.

The use of GC therapy is justified both in Bell's palsy [7, 8 ] and in facial nerve palsy developing as a result of surgical treatment of vestibular schwannoma to decrease inflammation and edema, but GC use may be limited by contraindications.

BoNT-A therapy is an effective method for the correction of mimic muscle tone, which is used in facial neuropathies of different origin $[19,20]$. The unilateral decrease of mimic muscle tone results in a significant increase of antagonistic muscle traction on the intact side, which leads to a constant stretching of paretic muscles [19, 21]. Based on our previous research in patients with facial nerve palsy developing after neurosurgical operations, we postulated that BoNT-A injections on the intact side - as in patients with acute facial nerve palsy - provided prolonged relaxation of the mimic muscles on the hyperactive intact side in patients with DFP. This leads to improved facial symmetry at rest and during movement of expression, resulting in more rapid recovery of function in the weak muscles on the injured side. Muscle recovery is due to a decrease of muscle hyperactivity on the intact side and decrease of traumatization by traction and stretching of paretic muscles on the injured side [21]. During the current study, we performed BoNT-A injections, with or without GC therapy, in patients with DFP, demonstrating its efficacy in improving the facial symmetry and the interaction of mimic muscles on both the intact and injured sides. The combined use of BoNT-A and GC therapy promoted more rapid recovery of facial symmetry, compared to other treatment modalities.

The small sample size and lack of placebo control are the main limitations to our study. Also, the observers were not blinded to the treatments that patients had received. Future research could also offer a comparison of the effects of BoNT-A in patients with acute facial palsy.

\section{CONCLUSION}

This study was the first to demonstrate the efficacy and safety of BoNT-A injections in patients with DFP developing after vestibular schwannoma resection. BoNT-A therapy demonstrated results comparable to GC therapy (standard treatment). BoNT-A injections may be recommended as a treatment option for patients with DFP to increase facial symmetry and improve functional recovery in cases of limitation or contraindication for GC therapy. GC therapy in combination with BoNT-A injections promotes more rapid recovery of facial nerve function.

\section{CONFLICT OF INTEREST AND SOURCES OF FUNDING}

None of the authors has any conflict of interest to disclose. This study was funded by Merz Pharmaceuticals $\mathrm{GmbH}$, Frankfurt am Main, Germany, in accordance with Good Publication Practice (GPP3) guidelines. The funding body did not influence the study design, the study conduct, preparation of the manuscript, or the decision to publish.

\section{DATA SHARING}

The authors confirm that the data supporting the findings of this study are available within the article.

\section{ACKNOWLEDGEMENTS}

The authors confirm that the data supporting the findings of this study are available within the article.

\section{REFERENCES}

1. Lee S, Seol HJ, Park K, Lee J-I, Nam D-H, Kong D-S, et al. Functional outcome of the facial nerve after surgery for vestibular schwannoma: prediction of acceptable long-term facial nerve function based on immediate postoperative facial palsy. World Neurosurg 2016;89:215-22.

2. Carlstrom LP, Copeland III WR, Neff BA, Castner ML, Driscoll CLW, Link MJ. Incidence and risk factors of delayed facial palsy after vestibular schwannoma resection. Neurosurgery 2016;78:251-5.

3. Morton RP, Ackerman PD, Pisansky MT, Krezalek M, Leonetti JP, Raffin MJ, et al. Prognostic factors for the incidence and recovery of delayed facial nerve palsy after vestibular schwannoma resection. J Neurosurg 2011;114:375-80.

4. Grant GA, Rostomily RR, Kim DK, Mayberg MR, Farrell D, Avellino A, et al. Delayed facial palsy after resection of vestibular schwannoma. J Neurosurg 2002;97:93.

5. Fenton JE, Chin RYK, Kalamarides M, Sterkers O, Sterkers J-M, Fagan PA. Delayed facial palsy after vestibular schwannoma surgery. Auris Nasus Larynx 2001;28:113-6.

6. Brackmann DE, Fisher LM, Hansen M, Halim A, Slattery WH. The effect of famciclovir on delayed facial paralysis after acoustic tumor resection. Laryngoscope 2008;118:1617-20.

7. Finsterer J. Management of peripheral facial nerve palsy. Eur Arch Otorhinolaryngol 2008;265:743-52.

8. Eviston TJ, Croxson GR, Kennedy PGE, Hadlock T, Krishnan AV. Bell's palsy: aetiology, clinical features and multidisciplinary care. J Neurol Neurosurg Psychiatry 2015;86:1356-61. 
9. Franco-Vidal V, Nguyen D-Q, Guerin J, Darrouzet V. Delayed facial paralysis after vestibular schwannoma surgery: role of herpes viruses reactivation - our experience in eight cases. Otol Neurotol 2004;25: 805-10.

10. Scheller C, Strauss C, Fahlbusch R, Romstöck J. Delayed facial nerve paresis following acoustic neuroma resection and postoperative vasoactive treatment. Zentralbl Neurochir 2004;65:103-7.

11. Gianoli GJ, Kartush JM. Delayed facial palsy after acoustic neuroma resection: the role of viral reactivation. Am J Otol 1996;17:625-9.

12. Ohata K, Nunta-aree S, Morino M, Tsuyuguchi N, Haque $\mathrm{M}$, Inoue $\mathrm{Y}$, et al. Aetiology of delayed facial palsy after vestibular schwannoma surgery: clinical data and hypothesis. Acta Neurochir 1998;140:913-7.

13. Sargent EW, Kartush JM, Graham MD. Meatal facial nerve decompression in acoustic neuroma resection. Am J Otol 1995; 16:457-64.

14. Olson JJ, Kalkanis SN, Ryken TC. Congress of Neurological Surgeons systematic review and evidencebased guidelines on the treatment of adults with vestibular schwannomas: executive summary. Neurosurgery 2018;82:129-34.

15. Ho SY, Hudgens S, Wiet RJ. Comparison of postoperative facial nerve outcomes between translabyrinthine and retrosigmoid approaches in matched-pair patients. Laryngoscope 2003;113:201420 .
16. Lee JM, Park HR, Choi YD, Kim SM, Jeon B, Kim H-J, et al. Delayed facial palsy after microvascular decompression for hemifacial spasm: friend or foe? J Neurosurg 2018;129:299.

17. Gordin E, Lee TS, Ducic Y, Arnaoutakis D. Facial nerve trauma: evaluation and considerations in management. Craniomaxillofacial trauma \& reconstruction 2015;8: 1-13.

18. Bebawy JF. Perioperative steroids for peritumoral intracranial edema: a review of mechanisms, efficacy, and side effects. J Neurosurg Anesthesiol 2012;24: 173-7.

19. Akulov MA, Orlova OR, Tabashnikova TV, Karnaukhov VV, Orlova AS. Facial nerve injury in neurosurgery: a rehabilitation potential of botulinum therapy. Zhurnal voprosy neirokhirurgii imeni $\mathrm{N} N$ Burdenko 2018;82:111-8.

20. Cooper L, Lui M, Nduka C. Botulinum toxin treatment for facial palsy: a systematic review. J Plast Reconstr Aesthet Surg 2017;70:833-41.

21. Akulov MA, Orlova OgR, Orlova AS, Usachev DJ, Shimansky VN, Tanjashin SV, et al. Incobotulinumtoxin A treatment of facial nerve palsy after neurosurgery. J Neurol Sci 2017;381:130-4. 